\title{
SÉRIE "Pedagogika”
}

https://doi.org/10.52058/2695-1592-2021-5(5)-7-19

\section{Oksana Kostenko}

Teacher, Higher vocational school 7 Kremenchuk Poltava region, Kremenchuk, Ukraine, e-mail: oksanakostenko09@gmail.com, https://orcid.org/0000-0002-6402-6504

\section{FORMATION OF PROFESSIONAL COMPETENCIES OF FUTURE ACCOUNTANTS ON REGISTRATION OF ACCOUNTING DATA BY INFORMATION AND COMMUNICATION TOOLS}

\begin{abstract}
Under the conditions of reforming the Ukrainian professional (vocational and technical) education, transition to multilevel training of future specialists, professional and competitive personnel, the issue of the competence approach acquires special urgency. The development of state educational policy in Ukraine should take into account the fact that all issues related to the use and implementation of information technology in educational institutions should be addressed holistically. The purpose of the academic paper lies in identifying the features of the formation of professional competencies of future accountants on the registration of accounting data by information technology tools. The research methodology is as follows: methods of logical comparison, systematization and generalization, general scientific and special research methods, in particular, the analysis and synthesis, system-structural analysis, method of expert evaluations, which has made it possible to achieve the research purpose. The importance of applying information technologies is focused on obtaining a qualitatively new result in the field of professional (vocational and technical) education, which would meet the state and trends of the world educational society and generally accepted international and European standards in this sphere.
\end{abstract}

Keywords: competence approach, structure of professional competencies, information technologies, informatization of educational process, online services.

Introduction. The concept of competence approach in education, including in vocational and technical, is aimed at developing the personality of a professional with a positive outlook, values, the ability to quickly adapt to traditional, new and unpredictable life and professional situations. Competence approach is an important

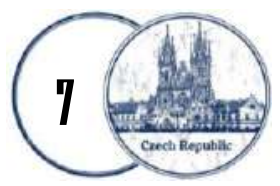


conceptual basis for the implementation of a new system of principles for defining the goals of vocational education, selection and structuring of the content of educational material, organization of the educational process and assessment of educational outcomes in order to achieve a sufficiently high future level of knowledge, experience, and awareness for professional activities. Therefore, the competence approach should be understood as a method of modelling the results of vocational education, their presentation in the form of quality standards for training skilled workers.

In the context of a global pandemic, the implementation of a competence approach requires the introduction of information and communication technologies in the educational process of vocational educational institutions. As a result, intensive development of education on the basis of information and telecommunication technologies becomes an important national priority of Ukraine.

Literature Review. The issue of the applying information technologies in the organization of the educational process of professional (vocational and technical) educational institutions is studied by a great amount of scientists. In particular, the scientific works of the scholars as follows: Kurepin V.M. [14], Naidiuk S.V. [4], Petrenko L.M. [15], Pogorelov S.M. [5], Sarmina Ye. Yu. [3], Siniakova V.S. [14], Us S.V. [14], Fomicheva T.L. [3], Lytvyn A. [6], Lytvyn V. [6], Rudenko L. [6], Ryzhkova I. [10], Shutenko E. [10], Shutenko A. [10], Sergeev A. [10], Talysheva I. [10], Tsareva E. [10] are devoted to the analysis of some aspects of the use of information technology in the modern educational sector of Ukraine in the framework of globalization processes and challenges that have influenced the development and formation of activities and organization of the educational process in professional (vocational and technical) education. Currently, the use of information technologies in the organization of the educational process of professional (vocational and technical) educational institutions remains insufficiently studied, and the analysis of scientific achievements of researchers gives grounds to assert the existence of different approaches in the study of this issue.

The purpose of the academic paper lies in identifying the features of the formation of professional competencies by means of information and communication technologies in the organization of the educational process of professional (vocational and technical) education; to form models for optimization of the maintenance and structure of information training, a choice of the corresponding information technologies for development of complex educational and methodical support of educational process; to identify e-services for the organization of blended and distance learning in connection with coronavirus infection COVID-19 .

Methods. The author has used methods of logical comparison, systematization and generalization, general and special research methods, including analysis and

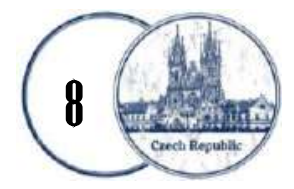


synthesis, system-structural analysis, the method of expert evaluations, which has made it possible to achieve the purpose of the research.

Presentation of the Basic Material of the Research. Competence approach in education is connected with personality-oriented and activity-based approaches to the educational and production process, forasmuch as it relates to the personality and can be implemented and tested only in the process of performing a certain set of actions.

The principal purpose of training future professionals in modern society lies in not obtaining a qualification in the chosen field, but acquiring and developing certain competencies that should enable him to adapt to the dynamic development of the modern world. This requires the introduction of appropriate changes in the content of professional training of future professionals. The basis of these changes is the formation of future professionals' professional competence. For this reason, "professional competence" is one of the main categories of the competence approach.

Professional competence is implemented in professional activity, which remains one of the most important forms of human interaction with the social environment. Professional competence combines a system of knowledge, skills and abilities objectively defined by normative documents; personal component - interests, aspirations, value orientations, motives of self-fulfilment of the individual; ability to solve this or that problem, to carry out active search of new experience and to define its inherent value, presence of abilities and skills of independence in planning, the organization, control of one's own activity.

The standard of professional (vocational and technical) education (SP (PT) O 4121.M.69.20 - 2018) on the vocational profession "Accountant on the registration of accounting data" defines the concept of "competence / competencies" as the ability of a person to perform a certain type of activity that is expressed through knowledge, skills, moral and ethical values and other personal qualities [16].

According to SP (PT) O 4121.M.69.20 - 2018, training on the profession "Accountant on the registration of accounting data" is based on a competence approach and is structured on a modular basis. The structure of the training module includes a list of competencies and their content, which is the basis for the development of a Standard program (curriculum) for training on the profession.

A Standard training program on the profession "Accountant on the registration of accounting data" includes the subjects of the professionaltheoretical cycle as follows: 1) Theory of accounting; 2) Accounting; 3) Business Economics; 4)Fundamentals of statistics; 5) Finance; 6) Information systems and technologies in accounting; 7) Fundamentals of taxation.

Let us consider in more detail the structure of professional competencies of the profession "Accountant on the registration of accounting data" in accordance with SP (PT) V 4121.M.69.20 - 2018 (Figure 1). 
The development and implementation of a model for the formation of professional competencies of future accountants on the registration of accounting data by means of information and communication technologies took place in four stages:

1. Search, analysis and study of information and communication technologies.

2. Development of complex educational and methodical support of subjects (EMSS) by means of information technologies.

3. Development and implementation of a model for the formation of professional competencies by means of information and communication technologies in the educational process for the training of future accountants on the registration of accounting data.

4. Conducting research and analyzing the results.

At the first stage, the works of domestic and foreign scientists on the application of information technologies in the organization of the educational process were studied.

Information technologies were tested in the educational process during distance and blended mode of training of future accountants (Figure 1). 


\section{PROFESSIONAL COMPETENCIES}

Formation of competencies in accounting theorv

Mastering the concept of business accounting, its role. Knowledge of the levels of statutory regulation of accounting.

Understanding of the subject and method of accounting

Mastering the concept of balance sheet. Drawing up a balance sheet

Mastering the structure of accounting records. Application of the double entry method to reflect business transactions on accounting records.

Understanding of the principle of construction and structure of the Chart of Accounts for drawing up the correspondence of accounts

Mastering the requirements for drafting documents, processing and storage of documents. Understanding of document management. The ability to systematize accounting documents and organize temporary storage of documents, transfer them to the archive. Mastering the method of inventory.

Mastering the forms of accounting, list and purpose of accounting registers. Knowledge of general information about the main accounting automation programs operating in Ukraine.

Mastering the accounting of basic economic processes. Maintaining primary accounting of inventories, fixed assets and other non-current tangible assets. Compilation of correspondence of accounting records operating in Ukraine.

\begin{tabular}{|c|}
\hline Mastering knowledge of accounting (financial accounting) \\
\hline Implementation of cash accounting \\
\hline Implementation of inventory accounting \\
\hline Mastering the accounting of non-current assets \\
\hline Implementation of accounting for settlement transactions \\
\hline Mastering the conducting accounting of own capital \\
\hline Implementation of accounting for costs, revenues and financial results in enterprise \\
\hline Mastering the fundamentals of accounting \\
\hline $\begin{array}{l}\text { Mastering knowledge of economic activity of the enterprise, statistics and } \\
\text { finance }\end{array}$ \\
\hline Mastering knowledge about the economic activity of the enterprise \\
\hline Mastering the fundamentals of statistics \\
\hline Mastering knowledge of finance \\
\hline Mastering the information systems and technologies in accounting \\
\hline General characteristics of information systems and technologies in accounting \\
\hline Automation of enterprise accounting \\
\hline Mastering the fundamentals of taxation \\
\hline Mastering the fundamentals of taxation \\
\hline
\end{tabular}

Fig 1. The structure of professional competencies of accountants for the registration of accounting data

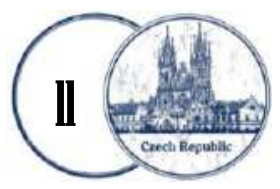


At the third stage, the training materials, developed with the help of information technologies, listed in Table 1, were summarized and systematized.

Table 1.

\begin{tabular}{|l|l|}
\multicolumn{1}{|c|}{ Basic electronic services for providing distance and blended learning } \\
\hline Moodle & \multicolumn{1}{c|}{ Features } \\
\hline Google CIassroom & $\begin{array}{l}\text { an application that helps organize a holistic online learning process } \\
\text { antication that that helps speed up the exchange of information } \\
\text { educational institutions }\end{array}$ \\
\hline OnlineTestPad & online designer of tests, surveys, crossword puzzles \\
\hline Google Forms & $\begin{array}{l}\text { an application that makes it possible to conduct a survey, but also to } \\
\text { make a guest list, collect e-mail addresses for newsletters and even } \\
\text { take a quiz }\end{array}$ \\
\hline $\begin{array}{l}\text { Skype, Viber, WhatsApp, } \\
\text { Zoom }\end{array}$ & $\begin{array}{l}\text { messengers for ensuring the process of communication of participants } \\
\text { in the educational process in real time }\end{array}$ \\
\hline Padlet & universal online board that is easy to use in the educational process \\
\hline Quizizz & $\begin{array}{l}\text { an application that makes it possible to generate tests and take them in } \\
\text { game form }\end{array}$ \\
\hline Liveworksheets & $\begin{array}{l}\text { web service that makes it possible to improve training materials } \\
\text { created in docx, pdf, jpg and png formats. It turns regular pages into } \\
\text { interactive self-test material. You can create worksheets that contain } \\
\text { several types of tasks }\end{array}$ \\
\hline Wizer.me & $\begin{array}{l}\text { service for creating interactive worksheets with tasks and exercises, } \\
\text { including video-based }\end{array}$ \\
\hline Nearpod & $\begin{array}{l}\text { an online platform that makes it possible to create presentations for } \\
\text { classes and share them with students during the lesson }\end{array}$ \\
\hline
\end{tabular}

A comprehensive educational and methodological support of subjects (EMSS) by means of information technologies was developed, namely: 1. Interactive collection of tasks on accounting (Part I). 2. Interactive training aid "Economic activity of the enterprise, statistics and finance". 3. Interactive textbook "Accounting". 4. Learning website "Information systems and technologies in accounting". 5. Learning website "Planet of Accounting". 6. Educational online platform for accountants in the Moodle system.

As a result of the systematization and generalization of the structural components of the EMSS, a model for the formation of professional competencies by means of information and communication technologies was developed (Figure 2).

This model provides the interconnection of the target, meaningful, educational and pedagogical and effective (resulting) components coordinating all structural components of the formation of professional competencies by means of information

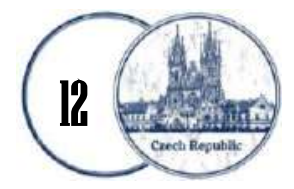


and communication technologies in the process of theoretical professional training of future accountants on registration of accounting data.

The target component is formed under the influence of the environment, namely the requirements of the labor market and the State standards of professional (vocational and technical) education. Accordingly, it has a significant effect on the design of the content, methods, forms and means of theoretical professional training based on the selected principles and performs certain functions in the formation of professional competencies of future accountants on the registration of accounting data by means of information and communication technologies.

The model of formation of professional competencies by means of information and communication technologies should meet the requirements defined by its principles, namely:

The principle of regularity of self-determined learning - stable and significant links between the structural components of the model, as a result of which effective outcomes are achieved in the formation of the future accountant on the registration of accounting data;

The principle of purposefulness - all structural components are subject to the overall goal of forming a future competitive specialist;

The principle of sequence - the structural components of the model have a clear sequence in the organization of distance and blended learning mode - from theory to practice;

The principle of connection with the profession - the use of structural components brings learning as close as possible to the real conditions of professional activity;

The principle of systematization - all structural components of the model are combined and interconnected.

The model of developing professional competencies of future accountants on registration of accounting data by means of information and communication technologies performs the functions as follows:

1) educational and developmental - it contributes to the systematization of knowledge, the formation of independence and the development of cognitive activity of students;

2) cognitive and practical - it encourages students to work systematically, achieve better results, overcome gaps in knowledge;

3 ) professionally - oriented - it contributes to the purposeful development of the abilities of students, the growth of their skills that will be needed in the process of future professional activity;

4) control - it is designed for identifying, measuring and assessing the results of educational and cognitive activities of students;

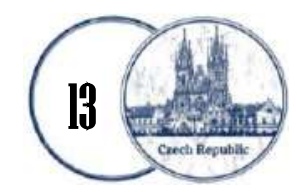


5) communicative - it helps provide feedback between the teacher and the student.

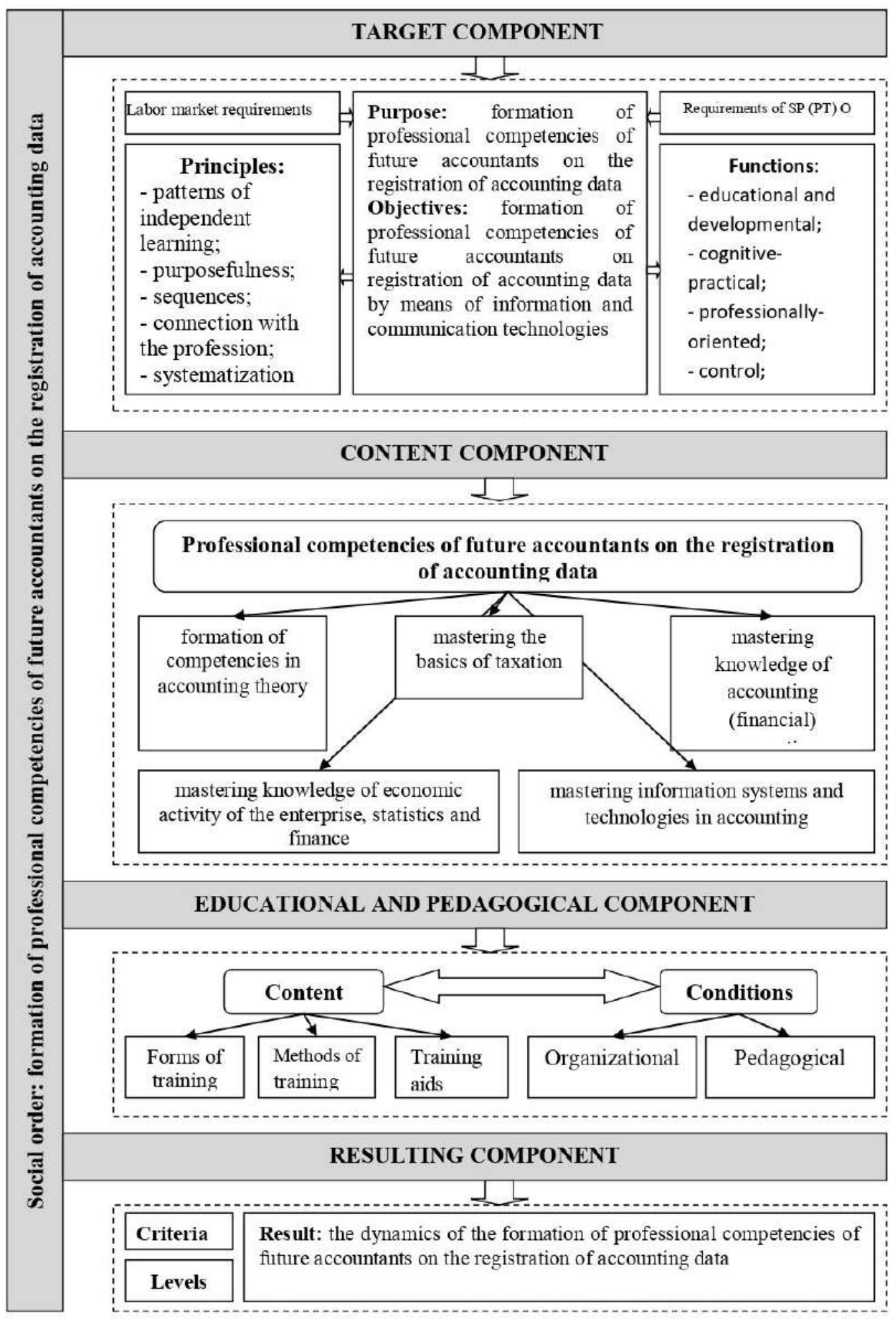

Fig. 2. Model of formation of professional competencies by means of information and communication technologies

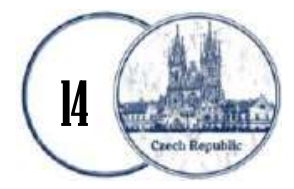


The content component of the model reveals the structure and content of professional competencies and reveals the links between subjects.

The educational and pedagogical component characterizes the content, forms, methods and means of learning; it demonstrates the material and technical, educational and methodological base, as well as conditions that will ensure the effectiveness of the formation of professional competencies of future accountants on the registration of accounting data by information and communication technologies.

The specified forms of training, corresponding to the model, include as follows: games (online quizzes, web quests, competitions, contests, etc.); interactive (joint projects, research, discussions, conferences); problem-based (business simulations classes creating conditions as close as possible to production conditions); innovative (using modern digital technologies and modern technologies); graduation assignment.

The model of developing professional competencies of future accountants on the registration of accounting data by means of information and communication technologies is characterized by the following teaching methods, namely: verbal; visual; practical; inductive; reproductive; creative; problem-searching.

The performance level of the model of developing professional competencies of future accountants on the registration of accounting data by means of information and communication technologies is achieved thanks to the application of teaching aids as follows: video lessons; multimedia presentations; online tests; online competitions, quizzes and competitions; web quests; electronic manuals; interactive manuals; video conferences; online simulators; business simulations; educational sites; electronic educational and methodical complexes.

The functioning progress of the model of developing professional competencies of future accountants on the registration of accounting data by means of information and communication technologies requires the implementation of the following conditions, namely:

I. Organizational conditions: free access to structural components; technical equipment of participants in the educational process; availability of feedback; objectivity and transparency of assessment; focus on the individuality of the individual.

II. Pedagogical conditions of application of the model: electronic educational and methodical support of the educational process, its updating on the basis of the competence approach; computerization and informatization of the educational process of theoretical and professional training of future accountants on the registration of accounting data; use of online services and information technologies in the organization of the educational process; computer literacy of participants in the educational process.

The resulting component of the model characterizes the degree of achievement

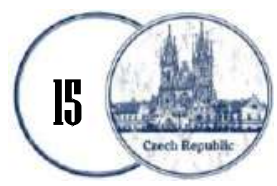


of the goal. It provides the targeted systematic diagnostics and identification of the main directions of improving the level of professional competencies of future accountants on the registration of accounting data by means of information and communication technologies, conducted in the framework of monitoring the quality of education.

The following criteria for assessing the effectiveness of the model were identified, namely: motivational; cognitive; professional activity. According to the levels of manifestation of the selected indicators, three levels of efficiency according to these criteria have been revealed, namely: high, medium, low.

The resulting component performs the function of diagnostics and correction, forasmuch as it is associated with the organization of control and assessment of the formation level of professional competencies on the basis of certain criteria and indicators of the level of its development.

This component coincides with the fourth stage of development and implementation of the model "Conducting the research and analysis of results".

The analysis of the results of the research conducted, namely the results of the defense of graduation theses, as well as assessment was carried out by the method of expert evaluations. The experts were accountants of enterprises - customers of personnel, leading specialists in the training of accountants on the registration of accounting data.

As a result of the research conducted, it has been established that the introduction of a model of formation of professional competencies of future accountants on the registration of accounting data by means of information and communication technologies can increase the quality of writing and defense of graduation theses by $15,88 \%$.

Therefore, the developed model of formation of professional competencies of future accountants on registration of accounting data by means of information and communication technologies is a complex structure consisting of interconnected elements and components; it is focused on the future professional activity of an accountant on registration of accounting data.

Discussion. Analyzing the current state of application of information technologies in the formation of professional competencies of future accountants on the registration of accounting data in institutions of professional (vocational and technical) education showed that, despite significant advances in this area and the development of the problem as a whole, the possibilities of optimizing the training of skilled workers on the basis of ICT have been insufficiently studied. That is, the lack of comprehensive analysis and classification of relevant pedagogical software and other e-learning tools is observed. There is no clear methodology for assessing the quality of information resources and technologies used in the formation of

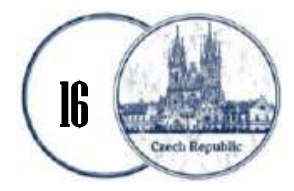


professional competencies in a blended and distance learning mode in vocational educational institutions, and there are no guidelines for their effective use.

Approbation and results of the present research emphasize the fact that a sound and experimentally tested model of formation of professional competencies of future accountants on the registration of accounting data by information and communication technologies provides interaction of all elements of theoretical and professional training by information technologies, which accurately reflects its basic properties and predicts results of developing professional competencies. Therefore, it is necessary to address complex issues of regulatory, educational, methodological, personnel, organizational and financial support of information technologies in the process of training future accountants on the registration of accounting data.

Conclusion. Introduction of complex electronic educational and methodical support of subjects of theoretical and professional training of future accountants on registration of accounting data in the organization of educational process of institutions of professional (vocational and technical) education promotes increase of educational process efficiency. Information technologies and systems are management tools serving to form the professional competencies of future skilled workers. In order for information technologies to act effectively in the formation of professional competencies, it is necessary to carry out appropriate changes in the entire system, which should include both the improvement of the organizational structure of the educational institution and the introduction of a competence approach to the provision of quality education. Ensuring a rational choice of a software product, adequate for a particular professional (vocational and technical) educational institution for the automation of internal educational processes and its effective use in the learning process in complex systems makes it possible for the educational institution to provide as follows: generalization and deepening of the theoretical knowledge of future employees; training and mastering the basic principles of professional activity; development of algorithmic style and culture of students' thinking; mastering the general means of informatization, formation of skills and abilities in the profession, mastering the methods of working with ICT; studying and mastering the methods and means of using modern ICT in accordance with the needs of future professional activities; updating professional knowledge and skills taking into account the possibilities of ICT; formation of ICT resource planning skills required to perform professional tasks; development of communicative abilities, skills of collective work; acquaintance with modern methods of research and design activities in the professional field.

A promising area of further research on the issue outlined lies in improving the formation of professional competencies based on ICT, including the creation and implementation of educational and methodological training systems, planning of

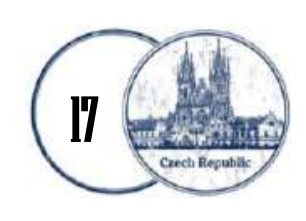


distance and mixed type of vocational training, development of electronic support and maintenance tools.

\section{References:}

1. Cuban L. Oversold and underused: Computers in the classroom. Cambridge: Harvard University Press, Cambridge, MA. 2001. URL: https://moodle.fct.unl.pt/pluginfile.php/72068/ mod_resource/content/0/Cuban_2001_Oversold_and_underused_Computers_in_the_classroom.pdf (data zvernennja: 10.02.2021).

2. Fuchs T., Woessmann L. Computers and student learning: Bivariate and multivariate evidence on the availability and use of computers at home and at school. 2005. URL: https://www.ifo.de/DocDL/IfoWorkingPaper-8.pdf (data zvernennja: 10.02.2021).

3. Sarmyna E. Ju., Fomycheva T. L. Ynformacyonnыe tekhnologhyy kak ynnovacyja v systeme upravlenyja. Ynteraktyvnaja nauka. 2017. № 1 (11). S. 197-199.

4. Najdjuk S. V. Vykorystannja novitnikh informacijnykh tekhnologhij u procesi pryjnjattja upravlinsjkykh rishenj. Demokratychne vrjaduvannja. 2013. Vyp. 12. URL: http://www.lvivacademy.com/vidavnitstvo_1/visnik12/fail/Najdjuk.pdf (data zvernennja 10.02.2021).

5. Poghorjelov S. M. Osoblyvosti zastosuvannja informacijnykh tekhnologhij v menedzhmenti ta ekonomici. Visnyk Nacionaljnogho tekhnichnogho universytetu "Kharkivsjkyj politekhnichnyj instytut" (ekonomichni nauky) : zb. nauk. pr. Kharkiv : NTU "KhPI", 2018. № 19 (1295). S. 151-155.Lytvyn A., Lytvyn V., Rudenko L. et al. Informatization of technical vocational schools: Theoretical foundations and practical approaches. Education and Information Technologies. 2020. vol. 25. pp. 583-609. URL: https://doi.org/10.1007/s10639-019-09966-4 (data zvernennja: 10.02.2021).

6. Markauskaite L. Critical review of research findings on information technology in education. Informatics in Education, 2003. vol. 2(1), pp. 65-78.

7. Shutenko, E. N. Motivational and Conceptual Aspects of Student Self-fulfillment in University Education. Procedia - Social and Behavioral Sciences, 2015. vol. 214(5), pp. 325-331. URL: doi: 10.1016/j.sbspro.2015.11.652 (data zvernennja: 10.02.2021).

8. Shutenko A. I., Shutenko E. N., Sitarov V.A., Romaniuk L.V. Psychological possibilities and functions of modern information technologies as the means for students' self-realization in university training. International Journal of Pharmaceutical Research and Allied Sciences, 2017. vol. 6(1), pp. 130-144.

9. Shutenko E., Shutenko A., Sergeev A., Ryzhkova I., Talysheva I., Tsareva E. The use of modern ICT to provide students' self-realization in Russian higher school. Revista Espacios, 2018. vol. 39(43).

10. Shutenko E., Shutenko A., Sergeev A., Ryzhkova I., Talysheva I., Tsareva E. The use of modern ICT as tools for development of learning communication in the contemporary university. Revista Espacios, 2019. vol. 40(15).

11. Martin, W., Gersick, A., Nudell, H., \& Culp, K. M. An evaluation of Intel teach to the future. Year Two Final Report. September 2002. Center for Children and Technology, New York. 2002. URL: https://www.academia.edu/27425031/An_evaluation_of_Intel_Teach_to_the_Future_ Year_two_final_report (data zvernennja: 10.02.2021).

12. Postanova Kabinetu Ministriv Ukrajiny vid 11.03.2020 \# 221 ta nakaz Ministerstva osvity i nauky Ukrajiny vid 16.03.2020 \# 406 «Pro orghanizacijni zakhody dlja zapobighannja poshyrennju koronavirusu COVID-19». URL: https://zakon.rada.gov.ua/rada/show/v040672920\#Text (data zvernennja: 10.02.2021).

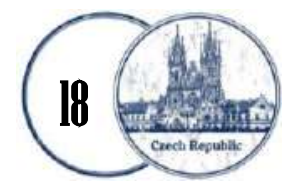


13. Kurepin V. M., Synjakova V. S., Us S. V. Orghanizacija osvitnjogho procesu v zakladakh profesijnoji (profesijno-tekhnichnoji) osvity na period karantynu // Aktualjni problemy zhyttjedijaljnosti ljudyny v suchasnomu suspiljstvi : tezy dopovidej zdobuvachiv vyshhoji osvity inzhenerno-energhetychnogho fakuljtetu ta inshykh uchasnykiv osvitnjogho procesu za rezuljtatamy tematychnogho «krughlogho stolu» na inzhenerno-energhetychnomu fakuljteti, $\mathrm{m}$. Mykolajiv, 18-20 lystopada 2020 r. Mykolajiv : Mykolajivsjkyj nacionaljnyj aghrarnyj universytet, 2020. S. 132-135.

14. Petrenko L. M. Teoretyko-metodologhichni pidkhody do zabezpechennja dystancijnogho navchannja $\mathrm{v}$ zakladakh profesijnoji (profesijno-tekhnichnoji) osvity. Visnyk Ghlukhivsjkogho nacionaljnogho pedaghoghichnogho universytetu imeni Oleksandra Dovzhenka. Ser.: Pedaghoghichni nauky. 2018. Vyp. 2(2). S. 90-96. URL: http://nbuv.gov.ua/UJRN/vgnpu 2018_2(2)_14 (data zvernennja: 10.02.2021).

15. Standart profesijnoji (profesijno-tekhnichnoji) osvity SP(PT)O 4121.M.69.20 - 2018. Nakaz Ministerstva osvity i nauky Ukrajiny vid « 04 » bereznja 2019r. № 300 . 